\title{
Distribution modelling as an approach to the conservation of a threatened alpine endemic butterfly (Lepidoptera: Satyridae)
}

\author{
MaArten De GROOT ${ }^{1}$, Franc REBEUŠEK ${ }^{2}$, Vesna GROBELNIK² ${ }^{2}$ MariJan GOVEDiČ², Ali ŠALAMUN² \\ and RUDI VEROVNIK ${ }^{3}$
}

\author{
${ }^{1}$ Department of Entomology, National Institute of Biology, Večna pot 111, Ljubljana, Slovenia; e-mail: maarten.degroot@nib.si \\ ${ }^{2}$ Center of Cartography of Fauna and Flora, Antoličičeva 1, SI-2204 Miklavž na Dravskem polju, Slovenia \\ ${ }^{3}$ Department of Biology, University of Ljubljana, Večna pot 111, Ljubljana, Slovenia; e-mail: rudi.verovnik@bf.uni.lj.si
}

Key words. Distribution modelling, habitat requirements, endemic species, high alpine grassland species, Lepidoptera, Satyridae, Satyrinae, Erebia calcaria, habitat structure specialist

\begin{abstract}
Mountain butterfly species are often restricted in their distribution and under threat from habitat destruction and climate change. Due to the inaccessibility of their habitats the distributions of many such species are unknown. We have investigated whether information on the habitat requirements of the Alpine endemic species Erebia calcaria could be used for modelling its potential distribution. We surveyed part of its range using transects and recorded habitat and environmental parameters. The most important parameters determining the presence of the species were average height of the vegetation, maximum height of the vegetation, percentage area of bare ground, number of food plants and slope. Furthermore, the abundance of E. calcaria is strongly affected by site exposure and grazing intensity. Using these results we modelled the potential distribution of the species in its known historical range in Slovenia. In the region covered by the model $70 \%$ of the records of $E$. calcaria were within the predicted distribution. It is reasonable to propose that such a high detection rate justifies the use of distribution models for predicting a species range and providing important additional information for their conservation. In the case of $E$. calcaria, we have shown that endemic mountain butterflies can be strongly threatened by fragmentation of their habitat, overgrazing and succession, which could be further amplified by changes in climate.
\end{abstract}

\section{INTRODUCTION}

Endemic species are threatened worldwide by habitat destruction and climate change (Brooks et al., 2002; Thomas et al., 2004; Hoyle \& James, 2005). These changes have a strong negative effect on species with low dispersal ability, including many terrestrial invertebrates (Thomas et al., 2004). Due to climate change, species tend to expand northwards and/or to higher altitudes, or to retreat to areas with advantageous topographic and microclimatic conditions (Hill et al., 1999, 2002; Konvička et al., 2003; Hickling et al., 2006; White \& Kerr, 2006; Wilson et al., 2007).

Due to the low mobility of mountain endemics or lack of suitable habitats in nearby mountains, they are not able to migrate northwards and are confined to a restricted range. Additionally, they are threatened by habitat changes (Kullman, 2002; Dullinger et al., 2004; Van Swaay et al., 2006) caused by human interference and climate change. Because of these factors, mountain endemics face an exceptionally high risk of extinction (Thomas et al., 2004).

One of the most important prerequisites for the successful conservation of endemic species is the availability of information on their distribution. This is often in short supply in countries with a high biodiversity and large numbers of endemics. This is well exemplified by the disproportionate availability of distribution data on butterflies in Europe. Detailed atlases are available for many species-poor countries, such as the Netherlands (Bos et al., 2006) and Great Britain (Asher et al., 2001), but the records published for southern Europe, where most of the endemic butterfly species are found, are far more scattered (Kudrna, 2002). Spatial modelling can provide an insight into the potential ranges of species for which data are limited (Palma et al., 1999; Luoto et al., 2002; Engler et al., 2004). Distribution modelling is particularly valuable for species confined to habitats in less accessible areas.

This paper presents the results of a study of the distribution and conservation status of Lorković's Brassy Ringlet Erebia calcaria Lorković, 1949, a mountain endemic from the Erebia tyndarus species group occurring in the Alps in the eastern part of Italy, southern part of Austria and alpine part of Slovenia (Lorković, 1957; Lorković \& De Lesse, 1960; Rakosy \& Jutzeler, 2005). With approximately $70 \%$ of the population, Slovenia contains the bulk of the worldwide distribution of this species (Van Swaay \& Warren, 1999). It is protected under the EC Habitat directive (Appendices II and IV), although it is not considered as a threatened species in Europe (Van Swaay \& Warren, 1999). So far, only a small part of its distribution has been documented (Čelik et al., 2004; Rakosy \& Jutzeler, 2005; Rebeušek et al., 2006) and its habitat requirements are based on anecdotal descriptions (Lorković, 1957; Čelik et al., 2004; Rakosy \& Jutzeler, 2005). E. calcaria occurs mainly on southern exposed grassy slopes, where the larval food plants are grasses 


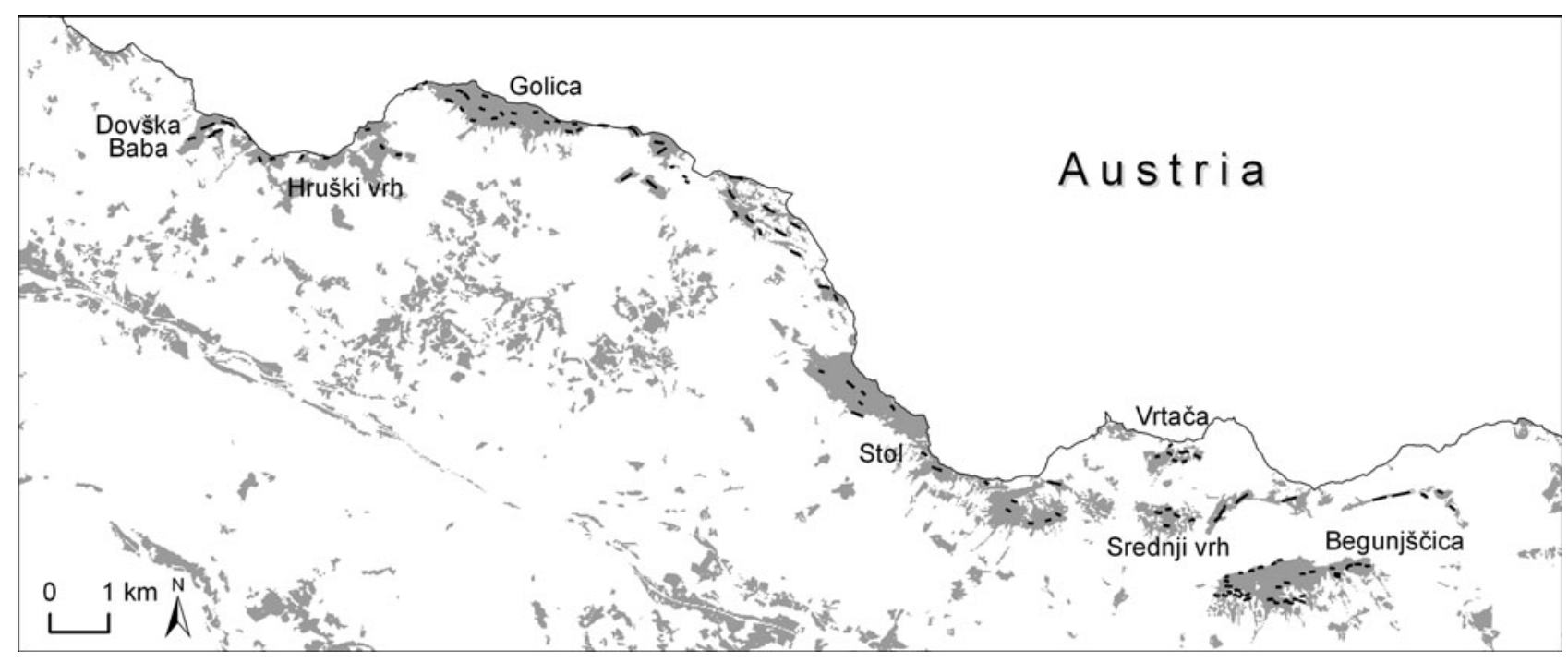

Fig. 1. Study area in the western Karavanke, with transects indicated by thick black lines.

like Sesleria caerulea (L.) Ard., Nardus stricta L. and Festuca spp. (Lorković, 1957; Rakosy \& Jutzeler, 2005).

The main objective of our study was to determine whether habitat modelling could be used to reveal the potential distribution of a species, information essential for the effective conservation of a species. The habitat requirements of the species were selected to include human imposed habitat changes. The eventual aims were to determine the true conservation status of E. calcaria and to identify the main threats to its survival. Finally, an attempt is made to identify potential declines and threats facing butterflies in sub-alpine regions, which have received little attention compared to lowland xerothermic or humid grasslands butterfly specialists.

\section{MATERIAL AND METHODS}

\section{Study sites}

The Karavanke Mountains, Julian Alps and KamnikeanSavinian Alps form the most south-easterly part of the Alps (Fig. 1). The majority of the fieldwork was carried out in the Karavanke Mts, an east to west orientated chain of mountains on the border of Slovenia and Austria. Geologically, they consist mainly of calcareous rock. The study area included mountain peaks in the western part of the Karavanke. The grasslands occupy slopes above approximately $1300 \mathrm{~m}$, stretching up to $2236 \mathrm{~m}$, dominated by Seslerio-Caricetum sempervirentis Br.-B1. in Br.-B1. et Jenny 1926 and Caricion ferrugineae G. Br.-Bl. et J. Br.-Bl. 1931 associations. The timberline is dominated by Norway spruce (Picea abies (L.)), in some areas also European Beech (Fagus sylvatica L.) and European Larch (Larix decidua Miller). The timberline in Karavanke is between 1600 and $1800 \mathrm{~m}$ and has been lowered in areas suitable for pasturing. The grasslands in the study area are highly fragmented and divided by at least 1 to $2 \mathrm{~km}$ of forested areas between peaks. They are mainly grazed at various intensities by sheep, cows or horses.

The area modelled includes most of the Alps in Slovenia, from the Julian Alps in the west to Kamnikean-Savinian Alps in the east. Compared to the Karavanke Mts, these areas generally have even more fragmented mountain grasslands, except for the southern chain of the Julian Alps. All the other habitat features and their management are similar to those in the Karavanke Mts.

\section{Survey protocol}

As E. calcaria is the only member of the tyndarus group present in Slovenia field identification was straightforward. Butterflies were counted along transects approximately $100 \mathrm{~m}$ long and $5 \mathrm{~m}$ wide, following a standard protocol (Pollard \& Yates 1993). Transects were generally situated in apparently homogenous grassland habitats above $1100 \mathrm{~m}$ and with a southern exposure. The transects were mostly perpendicular to the slope and at an average distance apart of $220 \mathrm{~m}($ s.e. $=11.9)$. Slopes with a northern exposure were not included in the survey as they are nearly vertical and lack grassland. Altogether 118 transects were surveyed from 2005 to 2007 (Rebeušek et al., 2006; with additional transects in 2007). The transects were surveyed only when the weather was dry, temperature at least $17^{\circ} \mathrm{C}$ and cloud cover less than $40 \%$ (Pollard \& Yates, 1993).

A habitat plot of 10 by $10 \mathrm{~m}$ was established randomly along each transect. The following habitat parameters were measured in the plot: average height of the vegetation $(\mathrm{cm})$, maximum height of the vegetation $(\mathrm{cm})$, cover of rock and bare soil $(\%)$, cover of Festuca spp. (\%), number of bushes (e.g. Pinus mugo Turra), number of trees (e.g. P. abies), number of flowering plants and number of flowering plant species. The following management parameters were measured: intensity of grazing (zero / moderate / intensive) and type of livestock. Intensive grazing was identified by the shortness of the grass $(<10 \mathrm{~cm})$ and/or erosion of the soil by trampling (bare ground $>15 \%$ per $\mathrm{m}^{2}$ ). In addition, many grazers or signs of grazers (e.g. faeces) were observed. Moderately grazed areas had grass higher than $10 \mathrm{~cm}$ and/or less than $15 \%$ bare ground per square meter and signs of grazers. If there were no tracks of livestock such areas were defined as ungrazed.

\section{Analyses}

Logistic regression was used to determine the preference of $E$. calcaria for particular habitat parameters and habitat types. Binomial distribution was used to estimate the effect of the parameters on the presence of E. calcaria. Both unimodal and linear relations were taken into account in the analysis. The statistical program $\mathrm{R}$ statistics was used for all calculations ( $\mathrm{R}$ Development Core Team, 2006). 


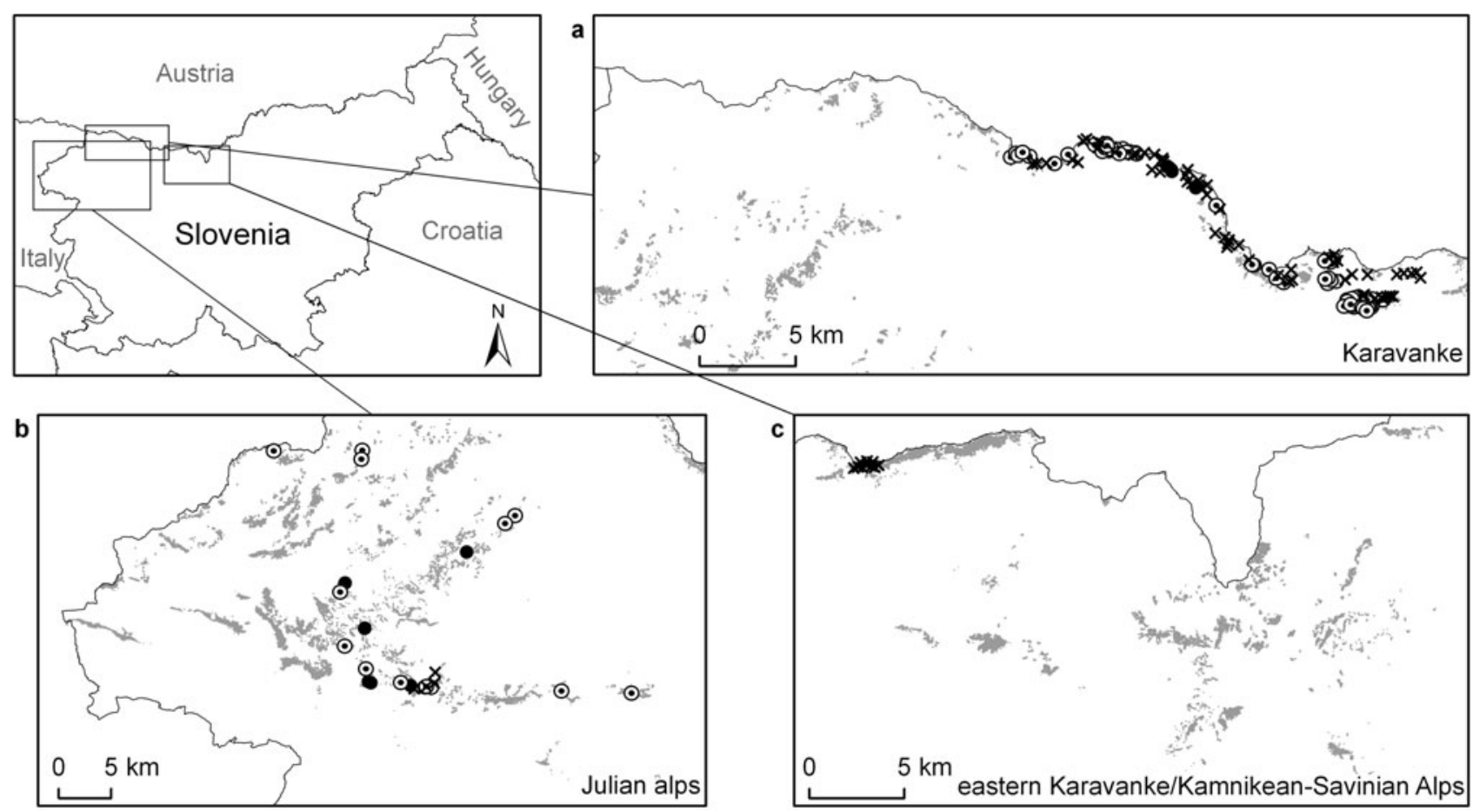

Fig. 2. Potential distribution of Erebia calcaria (Lorković, 1949) in (a) the Karavanke Mountains, (b) the Julian Alps and (c) the Kamnikean Savinian Alps. The areas shown on the map are those for which the predicted probability of the presence of $E$. calcaria was greater than 0.55 . Half-empty dots indicate occupied sites for which the predicted probability was more than 0.55 . The filled dots indicate occupied sites for which the model predicted a probability of less than 0.55 . The crosses indicate areas within the predicted distribution not occupied by E. calcaria.

We analysed two datasets, which included different kinds of data, using logistic regression: (1) habitat variables measured in the field (model 1) and (2) only topographical and land use parameters (model 2). The latter model was used for modelling the distribution.

In addition, we separately determined the effect of grazing intensity on the occurrence of E. calcaria.

\section{Distribution model}

The distribution model was based on the significant habitat and management parameters, which could be evaluated based on available GIS land use and topographical layers (MKGP 2007a, b). We applied the model to alpine grasslands in the Julian Alps and the eastern Karavanke/Kamnikean-Savinian Alps using ArcviewC. The Julian Alps were included as a known centre of the distribution of E. calcaria and the eastern Karavanke/ Kamnikean-Savinian Alps, with only a few unconfirmed records (Čelik et al., 2004), was used to test the predictions of the model. In order to test the predictive value of the model, alpine grasslands in an unexplored part of the Julian Alps were checked for the occurrence of E. calcaria during summer 2007. In addition, observations of E. calcaria over the previous five years were also used to check how the prediction of the distribution fits the model. All observation points in and $50 \mathrm{~m}$ around the modelled area were included as positives for the model. Therefore an area of $50 \mathrm{~m}$ radius around each observation point was made, to see if it overlapped with the modelled area. This was done for two reasons. First, E. calcaria is known to disperse from large open areas and therefore may be found outside its preferred habitat. Secondly, there are both errors in accuracy of the old records and in the overlaying of different topographic layers, as the suitable areas are often smaller than they appear.

As only land use and topographical data are available for other parts of the Slovenian Alps, models incorporating parame- ters measured in the field were validated as follows. The data were randomized and partitioned into 5/6ths for developing and $1 / 6$ th for validating the model. For validating the Julian Alps model and selected datasets for the other models, a receiver operating characteristic (ROC) plot was made and the metric area under the ROC curve (AUC) calculated (Fielding \& Bell, 1997). An AUC value of 0.5 is considered not to be better than random, while 1 is the most explanatory model. In addition, the model was evaluated by calculating the MaxKappa index (Guisan et al., 1998). First, several Kappa indices were calculated on different habitat suitability thresholds ranging from 0 till 1 . The habitat suitability threshold separates the unsuitable areas (habitat suitability below threshold) where the species should be absent, from the suitable areas (habitat suitability above threshold) where the species should be present. From these indices, the highest Kappa index (MaxKappa) was taken for the evaluation of the model. A Maxkappa value varies from -1 to 1,0 indicating that the model's predictions are no better than random and high values indicate that there is a good agreement between the prediction and data.

\section{RESULTS}

E. calcaria was observed on 60 out of 118 transects (Fig. 2a). The species was found on Mt. Begunjščica $(71 \%$ of 34 transects, $n$ (individuals seen) $=104)$, Dovška baba $(100 \%$ of 5 transects, $n=48)$, Golica $(58 \%$ of 19 transects, $n=44)$, Hruški vrh ( $14 \%$ of 7 transects, $n=3)$, Srednji vrh ( $100 \%$ of 5 transects, $n=10)$, Stol (31\% of 16 transects, $n=15)$, Struška ( $28 \%$ of 18 transects, $n=28$ ) and Vrtača ( $44 \%$ of 9 transects, $n=16)$. It was not found on Belščica, Košuta, Ljubelj and Zelenica mountains. 
TABle 1. The key habitat and other variables included in the E. calcaria distribution model. * indicates the model used for predicting the potential distribution.

\begin{tabular}{|c|c|c|c|c|c|}
\hline Models & & Estimate & s.e. & $z$ value & $P$ \\
\hline \multirow[t]{7}{*}{ Model 1} & (Intercept) & -7.75 & $1.86 \mathrm{E}$ & -4.2 & $<0.001$ \\
\hline & average vegetation & $6.80 \mathrm{E}-02$ & $3.01 \mathrm{E}-02$ & 2.3 & $<0.05$ \\
\hline & maximum vegetation height & $-3.39 \mathrm{E}-03$ & $1.37 \mathrm{E}-03$ & -2.5 & $<0.05$ \\
\hline & slope & $1.76 \mathrm{E}-01$ & $4.60 \mathrm{E}-02$ & 3.8 & $<0.001$ \\
\hline & bare ground & $2.86 \mathrm{E}-01$ & $9.90 \mathrm{E}-02$ & 2.9 & $<0.01$ \\
\hline & no. of food plant species & $3.48 \mathrm{E}-01$ & $1.53 \mathrm{E}-01$ & 2.3 & $<0.05$ \\
\hline & bare ground $\times$ no. of food plant species & $-6.12 \mathrm{E}-02$ & $2.04 \mathrm{E}-02$ & -3.0 & $<0.01$ \\
\hline \multirow[t]{4}{*}{ Model 2* } & (Intercept) & $-7.12 \mathrm{E}+01$ & $2.93 \mathrm{E}+01$ & -2.4 & $<0.05$ \\
\hline & slope & $1.58 \mathrm{E}-01$ & $3.49 \mathrm{E}-02$ & 4.5 & $<0.001$ \\
\hline & altitude & $7.92 \mathrm{E}-02$ & $3.38 \mathrm{E}-02$ & 2.3 & $<0.05$ \\
\hline & altitude $^{\wedge} 2$ & $-2.34 \mathrm{E}-05$ & $9.71 \mathrm{E}-06$ & -2.4 & $<0.05$ \\
\hline
\end{tabular}

The presence of E. calcaria correlated positively with the average height of the vegetation and negatively with the maximum height of the vegetation (Table 1 ; model 1). It also preferred sites with an abundance of flowering plant species interspersed with bare ground. The effect of the amount of bare ground on the presence of Erebia calcaria was greater than the number of food plant species. The occurrence of butterflies was strongly positively correlated with the exposure of the slope. In total, $38 \%$ of the variability was explained by model 1 . Model 1 had a MaxKappa of 0.80 (threshold $=0.21$ ) and an AUC of 0.92 .

Model 2, which included information on land use and topography indicated that slope and a unimodal response to altitude accounted for the distribution of E. calcaria (Table 1; model 2). This model explained $30 \%$ of the variability.

Furthermore, the occurrence of E. calcaria was significantly higher in ungrazed $(t=2.813, \mathrm{df}=2, P<0.05)$ or moderately grazed areas $(t=3.373$, df $=2, P<0.001)$ than in heavily grazed areas (Fig. 3). Sheep were almost always responsible for moderate grazing, and cows and horses for heavy grazing. In general, less steep slopes (average $=26^{\circ}$ ) were more intensively grazed, than the

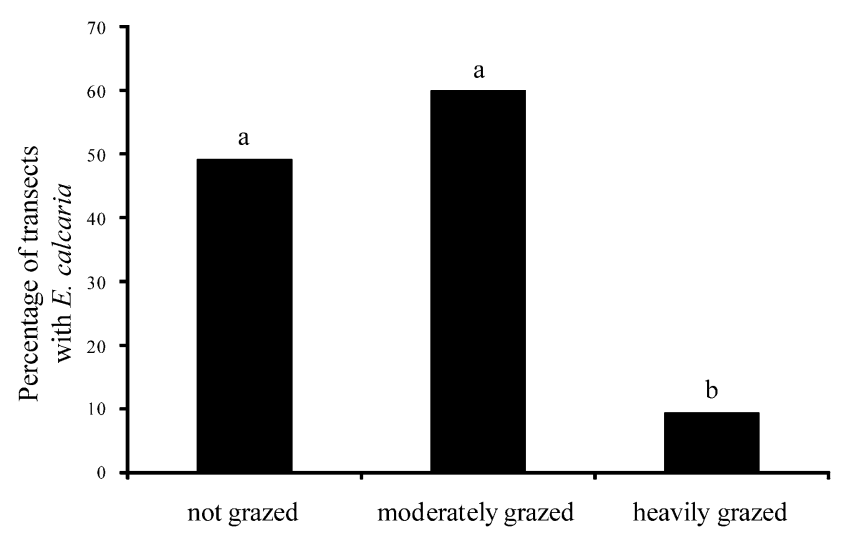

Fig. 3. Influence of intensity of grazing on the presence of $E$. calcaria. The letters above the columns indicate statistical differences between areas subject different grazing intensities based on a General Linearized Model. steeper slopes $\left(\right.$ average $\left.=34^{\circ}\right)\left(\chi^{2}=33.3\right.$, df $=2, P<$ $0.001)$.

The parameters of model 2 were selected in order to predict the potential distribution on alpine grassland. The resulting map shows patchy but widely available habitats throughout the Slovenian Alps. Potential sites were surveyed successfully in the Julian Alps on more than $70 \%$ of the visits (Fig. 2b) and only five of the previous records of E. calcaria were at sites with a probability lower than 0.55 . The AUC value was 0.78 and that of MaxKappa 0.5 (threshold $=0.01)$.

Despite large stretches of available habitat there are no confirmed records of the species from the eastern part of the Karavanke Mts and Kamnikean-Savinian Alps (Fig. 2c). The predicted chance of occurrence on Košuta, which is close to areas inhabited by E. calcaria, was very variable ranging from $0.17-1$ according to model 1 and 0.42-0.91 according to model 2.

\section{DISCUSSION}

\section{Factors affecting butterfly distribution}

Results of the explanatory habitat model indicate that within its limited distribution, E. calcaria prefer undisturbed grassland with a rich variety of food resources and patches of bare ground. The bare ground, represented by stones and soil, is used by adults for basking in the sun and for feeding on minerals. E. calcaria and E. epiphron Knoch, 1783 have similar habitat requirements (Konvička et al., 2002) and both fly at the same time throughout most of their ranges in Slovenia (e.g. Sonderegger, 2005; Čelik et al., pers. observ.).

The models explain only up to half of the variability in the habitat preferences of E. calcaria, which may be due to variability in the results or unintentional exclusion of explanatory parameters (Dormann et al., 2007). The former could be due to sampling in seemingly good habitats that are not occupied due to their isolation. These could therefore be considered as false negatives. Another reason is that certain explanatory parameters were not included in the survey. This was connected with the choice of transects, which were situated only in areas where the species was expected to be present (based on descriptions in Lorković, 1957; Rakosy \& Jutzeler, 2005). 
Thus there were no transects on northern rocky faces, or in habitats other than grassland, thus excluding potentially significant explanatory factors, such as other aspects or different land uses.

One of the highly positively correlated variables for the presence of the species was the steepness of the slope. This can be explained by the fact that steep slopes are not suitable for grazing by cows and horses, which removes the grazing pressure that affects the height of the sward and plant diversity (Fischer \& Wipf, 2002) and influences the availability of nectar for E. calcaria. Furthermore trampling by large animals also damages the turf, causing small scale erosion. Although bare ground is necessary for the presence of this species, sites heavily trampled by livestock often have too much bare ground. The second factor is the presence of larval food plants, which prefer steep slopes (Ellenberg, 1982; Lauber \& Wagner, 2001). Again, with increased steepness the percentage of bare ground increases and negatively affects the availability of food resources for adults and larvae, so E. calcaria is likely to become scarcer.

E. calcaria occurred only in areas of alpine grassland but its occurrence within this habitat depends on the distribution of resources (e.g. Kuras et al., 2000, 2003; Dennis et al., 2003, 2006; Vanreusel \& van Dyck, 2007). Therefore, its patchy distribution on alpine grasslands cannot be explained just by vegetation type, as is the case for some other butterfly species (e.g. Kerr \& Ostrovsky, 2003; Maes et al., 2003, 2004), but by the distribution of the resources. Some of the preferences of E. calcaria included in the measured parameters were already known (e.g. food plants and alpine meadows), others, like a strong correlation with grazing management, are unknown for this species.

\section{Potential distribution}

In applied biology it is important that the model's predictions apply to other areas (Rodriquez \& Andrén, 1999), otherwise it would only be of local use (Fielding \& Haworth, 1995; Rodriquez \& Andrén, 1999). In our case, models were validated using independent data from the Julian and Eastern Karavanke/Kamnean-Savinian Alps. The modelled potential distribution of E. calcaria agrees in large part with past field observations (Čelik et al., 2004) and was confirmed by surveys carried out in 2007. However, there is a sharp borderline in the central Karavanke Mountains, along the river Mošenik and the Ljubelj pass $(1370 \mathrm{~m})$. The few records east of this valley are unconfirmed and thus questionable (Čelik et al., 2004). Most surprising is the absence of the species from Mt. Košuta, just east of the divide, where the model detected one of the largest potentially suitable areas. This mountain is not obviously different in its natural history and range of habitats from the nearby Mt. Begunjščica on which E. calcaria is abundant. Since Mt. Košuta is higher than Mt. Begunjščica, the only obvious explanation is the extinction of E. calcaria caused by overgrazing in the past. In addition, the deep valley and forests between the two mountains could have hindered re-colonization of Mt. Košuta. Forests are important dispersal barriers to submontane Erebia medusa (Fabricius, 1787) (Schmitt et al., 2000) and the montane specialist E. epiphron in the Sudetan Mts, Czech Republic (Č́źžek et al., 2003, Schmitt et al., 2005). However, E. epiphron is present on both Mt. Košuta and Begunjščica, despite its low dispersal ability (Kuras et al., 2003; Schmitt et al., 2006). Further research is required to determine the fates of these two species on Mt. Košuta.

In general, distribution modelling is based on GISderived parameters (Hernandez et al., 2008) and therefore many habitat characteristics important for the survival of a species (e.g. food plant species number, average height of the vegetation, grazing management, etc.) are not included. In this study, the altitudinal belt, 1400 to 2100 $\mathrm{m}$, includes most of these parameters and therefore explains E. calcaria's potential distribution. Model validation for the Julian Alps had an AUC of 0.78. However, due to rapid changes in land use (Kullman, 2002) and uphill shifts due to climate change (Konvička et al., 2003; Wilson et al., 2007), an explanatory parameter like altitude is too imprecise, and temperature and habitat are likely to be better indicators of the species distribution. As most of the habitat data is not available in GIS layers, topographical data has to be used.

This study shows that distribution modelling of insects like butterflies in mountainous areas is useful for predicting the species' potential distribution. This approach is only suitable for species with a limited distribution and topographically defined habitat preferences. Such data could be helpful in planning distribution surveys. Certainly, the results could be interpreted only in terms of biogeography and are valid only within the range of the species. The E. calcaria model now needs to be tested in the eastern Italian calcareous Alps, where the distribution of this species is less well known.

\section{Conservation implications}

Alpine and subalpine grassland ecosystems and their biodiversity are under threat from succession, destruction and climate change (Fischer \& Wipf, 2002; Kullman, 2002; Wipf et al., 2005). Therefore, it is important to acquire as much information as possible about the habitat choice of potentially threatened endemic alpine species. This may facilitate the development of ways of conserving theses species and determining their potential distribution in less accessible regions. The results of speciesspecific studies, like this one on E. calcaria, might be applicable to other sympatric alpine butterfly species, especially when considering threats to their potential distribution.

One of the most surprising results of this study was the patchy and limited availability of potentially suitable sites for E. calcaria (Fig. 2b). The fact that the distribution of this species is even smaller than its potential distribution, makes this species one of the rarest and potentially most vulnerable butterflies in Europe. The existing populations are also under threat from habitat loss caused by anthropogenic disturbance, especially heavy grazing and grazing by large herbivores (horses, cows) (Fig. 3), and the building of ski resorts in areas where there are cur- 
rently suitable habitats. Heavy grazing is reported to have deleterious effects on many plant and animal species (Olff \& Ritchie, 1998, and references therein).

On the other hand, successional changes in the alpine and subalpine grasslands resulting in the development of shrub land or forests could be equally deleterious for the survival of E. calcaria in these areas. This is already identified as a threat for plant, bird, insect and mammal diversity in alpine and subalpine grasslands (Vandvik et al., 2005). For many centuries, the alpine grasslands that developed after the logging of forests were used as pastures. The steeper slopes were grazed by sheep and the more accessible areas by cows. However, grazing was rather sporadic and random. Now, in many parts of the Alps, farmers have abandoned the traditional way of managing alpine grasslands, which has resulted in the depletion of habitats due to overgrazing or overgrowing and the subsequent uphill shift in the tree line (e.g. Krahulec et al., 2001; Kullman, 2002; Dullinger et al., 2004; Albers et al., 2008). Although the uphill shifts in the distribution of trees are relatively slow (Mayer, 1976; Dullinger et al., 2004; Albers et al., 2008) it is predicted that increase in temperature will facilitate the dispersal of seed of trees (Dullinger et al., 2004), which will eventually colonize all the alpine grasslands.

Unlike the negative effects of heavy grazing described above, light pasturing had a positive effect on the occurrence of E. calcaria (Fig. 3) and is possibly the best way of managing the habitat for this species. The colonizing abilities of $E$. calcaria are well exemplified by the colonization of a newly established habitat that was clear-felled only a few years ago on Mt. Struška in the Karavanke Mountains. However, this evidence is only anecdotal and further studies are needed of population sizes, dynamics and dispersal in order to evaluate this species vulnerability to habitat fragmentation (Hanski et al., 1994; Gutiérrez et al., 1999; Sawchik et al., 2002; Krauss et al., 2004). As E. calcaria coexist with many other potentially threatened alpine and sub-alpine butterfly species, its conservation would have a wider effect. We hope that this study will enhance and motivate the conservation of this species and help Slovenia meet its obligations under the EU Habitats and Species Directive.

ACKNOWLEDGEMENTS. The field work in Karavanke was funded by the PHARE project Slovenia-Austria 2003 (7174201-01-01-0002). We thank H. Potočnik for statistical advice and R. Pain, M. Warren and M. Konvička for useful comments and improvements to previous versions of the manuscript.

\section{REFERENCES}

Albers C.H., Thuiller W., Lavorel S., Davies I.D. \& GarboLINO E. 2008: Land-use change and subalpine tree dynamics: colonization of Larix decidua in French subalpine grasslands. J. Appl. Ecol. 45: 659-669.

Asher J., Warren M. \& Fox R. 2001: The Millennium Atlas of Butterflies in Britain and Ireland. Oxford University Press, Oxford, $344 \mathrm{pp}$.

Bos F., Bosveld M., GroenendiJK D., van Swaay C., Wynhoff I. \& De Vlinderstichting 2006: De dagvlinders van Neder- land, verspreiding en bescherming (Lepidoptera: Hesperioidea, Papilionoidea. - Nederlandse Fauna 7. Nationaal Natuurhistorisch Museum Naturalis, KNNV Uitgeverij \& European Invertebrate Survey, Leiden, 348 pp.

Brooks T.M., MitTermeier R.A., Mittermeier C.G., DA Fonseca G.A.B., Rylands A.B., Konstant W.R., Flick P., Pilgrim J., Oldfield S., Magin G. \& Hilton-Taylor C. 2002: Habitat loss and extinction in the hotspots of biodiversity. Conserv. Biol. 16: 909-923.

Čelik T., Verovnik R., Rebeušek F., Gomboc S. \& Lasan M. 2004: Scientific Basis for Establishing of Network NATURA 2000: Butterflies (Lepidoptera) [Final Report]. Biological Institute Jovana Hadžija ZRC SAZU, Ljubljana, 297 pp. [in Slovenian].

Č́̇̌žeK O., Bakešová A., Kuras T., Beneš J. \& KonvičKa M. 2003: Vacant niche in alpine habitat: the case of an introduced population of the butterfly Erebia epiphron in the Krkonoše Mountains. Acta Oecol. 24: 15-23.

Dennis R.L.H., Shreeve T.G. \& van Dyck H. 2003: Towards a functional resource-based concept of habitat: a butterfly biology viewpoint. Oikos 102: 417-426.

Dennis R.L.H., Shreeve T.G. \& van Dyck H. 2006: Habitat and resources: the need for a resource-based definition to conserve butterflies. Biodiv. Conserv. 15: 1943-1966.

Dormann C.F., McPherson J.M., Araujo M.B., Bivand R., Bolliger J., Carl G., Davies R.G., Hirzel A., Hetz W., Kissling D., Kühn I., Ohlemühler R., Peres-Neto P.R., Reineking B., SchröDER B., Schurr F.M. \& WiLSON R. 2007: Methods to account for spatial autocorrelation in the analysis of distributional data: a review. Ecography 30: 609-628.

Dullinger S., Dirnböck T. \& Grabherr G. 2004: Modelling climate change-driven treeline shifts: relative effects of temperature increase, dispersal and invasibility. J. Ecol. 92: 241-252.

Ellenberg H. 1982: Vegetation Mitteleuropas mit den Alpen in ökologischer Sicht. Eugen Ulmer, Stuttgart, 1094 pp.

Engler R., Guisan A. \& Rechsteiner L. 2004: An improved approach for predicting the distribution of rare and endangered species from occurrence and pseudo-absence data. $J$. Appl. Ecol. 41: 263-274.

FieldiNg A.H. \& Bell J.F. 1997: A review of methods for the assessment of prediction errors in conservation presence/ absence models. Environ. Conserv. 24: 38-49.

Fielding A.H. \& HaworTh P.F. 1995: Testing the generality of bird-habitat models. Conserv. Biol. 9: 1466-1481.

FISCHER M. \& WIPF S. 2002: Effect of low-intensity grazing on the species-rich vegetation of traditionally mown subalpine meadows. Biol. Conserv. 104: 1-11.

Guisan A., Theurillat J.P. \& Kienast F. 1998: Predicting the potential distribution of plant species in an Alpine environment. J. Veg. Sci. 9: 65-74.

Gutiérrez D., Thomas C.D. \& LeÓN-Cortés J.L. 1999: Dispersal, distribution, patch network and metapopulation dynamics of the dingy skipper butterfly (Erynnis tages). Oecologia 121: 506-517.

HanSKi I., KUUSSAARI M. \& Nieminen M. 1994: Metapopulation structure and migration in the butterfly Melitaea cinxia. Ecology 75: 747-762.

Hernandez P.A., Franke I., Herzog S.K., Pacheco V., Paniagua L., Quintana H.L., Soto A., Swenson J.J., Tovar C., Valqui T.H., Vargas J. \& Young B.E. 2008: Predicting species ditributions in poorly-studied landscapes. Biodiv. Conserv. 17: $1353-1366$

Hickling R., Roy D.B., Hill J.K., Fox R. \& Thomas C.D. 2006: The distributions of a wide range of taxonomic groups are expanding northwards. Glob. Change Biol. 12: 450-455. 
Hill J.K., Thomas C.D. \& Huntley B. 1999: Climate and habitat availability determine $20^{\text {th }}$ century changes in a butterfly's range margin. Proc. R. Soc. Lond. (B) 266: 1197-1206.

Hill J.K., Thomas C.D., Fox R., Telfer M.G., Willis S.G., Asher J. \& Huntley B. 2002: Responses of butterflies to twentieth century climate warming: implications for future ranges. Proc. R. Soc. Lond. (B) 269: 2163-2171.

Hoyle M. \& JAMES M. 2005: Global warming, human population pressure, and availability of the world's smallest butterfly. Conserv. Biol. 19: 1113-1124.

Kerr J.T. \& Ostrovsky M. 2003: From space to species: ecological applications for remote sensing. Trends Ecol. Evol. 18: $299-305$.

KonvičKa M., Beneš J. \& Kuras T. 2002: Behaviour and microdistribution of two sympatric alpine butterflies (Erebia epiphron and E. euryale): relation to weather, vegetation and time of day. Biologia 57: 223-233.

KonvičKa M., Maradová M., Beneš J., Fric Z. \& KePKa P. 2003: Uphill shifts in distribution of butterflies in the Czech Republic: effects of changing climate detected on a regional scale. Glob. Ecol. Biogeogr. 12: 403-410.

Krahulec F., Skalovec H., Herben T., Hadincová V., Wildová R. \& PeCHÁČKovÁ S. 2001: Vegetation changes following sheep grazing in abandoned mountain meadows. Appl. Veg. Sci. 4: 97-102.

Krauss J., Steffan-Dewenter I. \& Tscharntke T. 2004: Landscape occupancy and local population size depends on host plant distribution in the butterfly Cupido minimus. Biol. Conserv. 120: $355-361$.

KUDRNA O. 2002: The distribution atlas of European butterflies. Oedippus 20: 7-343.

KulLman L. 2002: Rapid recent range-margin rise of tree and shrub species in the Swedish Scandes. J. Ecol. 90: 69-77.

Kuras T., Beneš J. \& KonvičKa M. 2000: Differing habitat affinities of four Erebia species (Lepidoptera: Nymphalidae, Satyrinae) in the Hrubý Jeseník Mts, Czech Republic. Biologia 55: 169-175.

Kuras T., Beneš J., Fric Z. \& KonvičKa M. 2003: Dispersal patterns of endemic alpine butterflies with contrasting population structures: Erebia epiphron and E. sudetica. Popul. Ecol. 45: $115-123$.

Lauber K. \& Wagner G. 2001: Flora Helvetica. 3th ed. Haupt, Bern, $1615 \mathrm{pp}$.

LoRKovič Z. 1957: Die Speziationsstufen in der Erebia tyndarus Gruppe. Biol. Glasn. 10: 61-116.

Lorković Z. \& De Less H. 1960: Erebia calcarius au Monte Cavallo au nord de Venise. Boll. Soc. Entomol. Ital. 90(7-8): 123-129.

Luoto M., Kuussaari M. \& Toivonen T. 2002: Modelling butterfly distribution based on remote sensing data. J. Biogeogr. 29: 1027-1037.

Maes D., Gilbert M., Titeux N., Goffart P. \& Dennis R.L.H. 2003: Prediction of butterfly diversity hotspots in Belgium: a comparison of statistically focused and land-use-focused models. J. Biogeogr. 30: 1907-1920.

Maes D., Vanreusel W., Talloen W. \& Van Dyck H. 2004: Functional conservation units for the endangered butterfly Maculinea alcon in Belgium (Lepidoptera: Lycaenidae). Biol. Conserv. 120: 229-241.

MAYER H. 1976: Gebirgswaldbau - Schutzwaldpflege. Fischer, Stuttgart, $436 \mathrm{pp}$.

McCullagh P. \& Nelder J.A. 1989: Generalized Linear Models. Chapman and Hall, London, $551 \mathrm{pp}$.

MKGP 2007a: Vectorized Map of Actual Use of Agricultural and Forestland. Ministry of Agriculture, Forestry and Food, Ljubljana [in Slovenian].
MKGP 2007b: Raster Map of Digital Relief Model of Slovenia (DMR5). Ministry of Agriculture, Forestry and Food, Ljubljana [in Slovenian].

OlfF H. \& Ritchie M.E. 1998: Effects of herbivores on grassland plant diversity. Trends Ecol. Evol. 13: 261-265.

Palma L., Beja P. \& Rodrigues M. 1999: The use of sighting data to analyse Iberian lynx habitat and distribution. J. Appl. Ecol. 36: 812-824.

Pollard E. \& YATES T.J. 1993: Monitoring Butterflies for Ecology and Conservation. Chapman \& Hall, London, 274 pp.

R Development Core Team 2006: R: A Language and Environment for Statistical Computing. R Foundation for Statistical Computing, Vienna, Austria. ISBN 3-900051-07-0, URL http://www.R-project.org.

Rakosy V.L. \& Jutzeler D. 2005: Biologie, Ökologie und Verbreitung des Karawanken-Mohrenfalters Erebia calcaria (Lorkovic, 1949) in Kärnten. Carinthia II 195: 675-690.

ReBeUŠEK F., JAKopič M. \& De Groot M. 2006: Inventarisation and Mapping of Habitats of Lorkovic's Ringlet (Erebia calcaria) with Proposal of Zonation of Natura 2000 Site Karavanke (SI3000285). Center of Cartography of Fauna and Flora, Miklavž na Dravskem polju, 42 pp. [in Slovenian].

RODRIGUEZ A. \& ANDRÉN H. 1999: A comparison of Eurasian red squirrel distribution in different fragmented landscapes. $J$. Appl. Ecol. 36: 649-662.

Sawchik J., Dufrêne M., Lebrun P., Schtickzelle N. \& BAGUETTE M. 2002: Metapopulation dynamics of the bog fritillary butterfly: modelling the effect of habitat fragmentation. Acta Oecol. 23: 287-296.

Schmitt T., Varga Z. \& Seitz A. 2000: Forests as dispersal barriers for Erebia medusa (Nymphalidae, Lepidoptera). Basic Appl. Ecol. 1: 53-59.

Schmitt T., Č́žĚEK O. \& KonvičKa M. 2005: Genetics of a butterfly relocation: large, small and introduced populations of the mountain endemic Erebia epiphron silesiana. Biol. Conserv. 123: 11-18.

Schmitt T., Hewitt G.M. \& Muller P. 2006: Disjunct distributions during glacial and interglacial periods in mountain butterflies: Erebia epiphron as an example. J. Evol. Biol. 19: 108-113.

Sonderegger P. 2005: Die Erebien der Schweiz (Lepidoptera: Satyrinae, Genus Erebia). Peter Sonderegger, Brügg bei Biel, $712 \mathrm{pp}$.

Thomas C.D., Cameron A., Green R.E., Bakkenes M., Beaumont L.J., Collingham Y.C., Erasmus B.F.N., de Siqueira M.F., Grainger A., Hannah L., Hughes L., Huntley B., van JaArsveld A.S., Midgley G.F., Miles L., Ortega-Huerta M.A., Townsend Peterson A., Phillips O.L. \& Williams S.E. 2004: Extinction risk from climate change. Nature 427: 145-148.

Van SwaAy C.A.M. \& Warren M.S. 1999: Red Data Book of European Butterflies (Rhopalocera). Nature and environment, no. 99, Council of Europe Publishing, Strasbourg.

Van SwaAy C.A.M., Warren M. \& Lois G. 2006: Biotope use and trends of European butterflies. J. Insect Conserv. 10: 189-209.

Vandvik V., Heedgaard E., Maren I.E. \& Aarrestad P.A. 2005: Managing heterogeneity: the importance of grazing and environmental variation on postfire succession in heathlands. J. Appl. Ecol. 42: 139-149.

VANREUSEL W. \& VAN DYCK H. 2007: When functional habitat does not match vegetation types: A resource-based approach to map butterfly habitat. Biol. Conserv. 135: 202-211. 
White P. \& KerR J.T. 2006: Contrasting spatial and temporal global change impacts on butterfly species richness during the 20th century. Ecography 29: 908-918.

Wilson R.J., Gutiérrez D., Gutiérrez J. \& Monserrat V.J. 2007: An elevational shift in butterfly species richness and composition accompanying recent climate change. Glob. Change Biol. 13: 1873-1887.

Wipf S., Rixen C., Fischer M., Schmid B. \& Stoeckli V. 2005: Effects of ski piste preparation on alpine vegetation. J. Appl. Ecol. 42: 306-316.

Received October 29, 2008; revised and accepted December 10, 2008 